\title{
GC-MS studies of the chemical composition of two inedible mushrooms of the genus Agaricus
}

Assya Petrova1, Kalina Alipieva1, Emanuela Kostadinova1, Daniela Antonova ${ }^{1}$, Maria Lacheva ${ }^{2}$, Melania Gjosheva ${ }^{3}$, Simeon Popov ${ }^{1}$ and Vassya Bankova*1

\author{
Address: ${ }^{1}$ Institute of Organic Chemistry with Centre of Phytochemistry, Bulgarian Academy of Sciences, 1113 Sofia, Bulgaria, ${ }^{2}$ Department of \\ Botany and Agrimeteorology, Agricultural University, 4000 Plovdiv, Bulgaria and 3Institute of Botany, Bulgarian Academy of Sciences, 1113 Sofia, \\ Bulgaria \\ Email: Assya Petrova - vassyab@yahoo.com; Kalina Alipieva - alipieva@orgchm.bas.bg; Emanuela Kostadinova - emanuela@orgchm.bas.bg; \\ Daniela Antonova - dantonova@orgchm.bas.bg; Maria Lacheva - agaricus@abv.bg; Melania Gjosheva - gyosheva@bio.bas.bg; \\ Simeon Popov - simpopov@orggchm.bas.bg; Vassya Bankova* - bankova@orgchm.bas.bg \\ * Corresponding author
}

Published: 20 December 2007

Chemistry Central Journal 2007, I:33 doi:10.1 186/1752-153X-1-33
Received: 31 October 2007

Accepted: 20 December 2007

This article is available from: http://journal.chemistrycentral.com/content/I/I/33

(C) 2007 Petrova et al;

This is an Open Access article distributed under the terms of the Creative Commons Attribution License (http://creativecommons.org/licenses/by/2.0), which permits unrestricted use, distribution, and reproduction in any medium, provided the original work is properly cited.

\begin{abstract}
Background: Mushrooms in the genus Agaricus have worldwide distribution and include the economically important species A. bisporus. Some Agaricus species are inedible, including A. placomyces and A. pseudopratensis, which are similar in appearance to certain edible species, yet are known to possess unpleasant odours and induce gastrointestinal problems if consumed. We have studied the chemical composition of these mushrooms using GC-MS.
\end{abstract}

Results: Our GC-MS studies on the volatile fractions and butanol extracts resulted in the identification of 44 and 34 compounds for A. placomyces and A. pseudopratensis, respectively, including fatty acids and their esters, amino acids, and sugar alcohols. The most abundant constituent in the volatiles and butanol were phenol and urea respectively. We also identified the presence of ergosterol and two $\Delta^{7}$-sterols. In addition, $5 \alpha, 8 \alpha$-Epidioxi-24( $\left.\xi\right)$-methylcholesta-6,22diene-3 $\beta$-ol was isolated for the first time from both mushrooms. Our study is therefore the first report on the chemical composition of these two species.

Conclusion: The results obtained contribute to the knowledge of the chemical composition of mushrooms belonging to the Agaricus genus, and provide some explanation for the reported mild toxicity of $A$. placomyces and $A$. pseudopratensis, a phenonomenon that can be explained by a high phenol content, similar to that found in other Xanthodermatei species.

\section{Background}

Mushrooms in the genus Agaricus have a worldwide distribution, with up to 90 species recorded in Europe. The genus includes the most economically important and commercially cultivated mushroom in the world, A. bis- porus (button mushroom) as well as many other edible species [1]. Some Agaricus species are inedible, including A. placomyces and A. pseudopratensis Bohus, which are similar in appearance to certain edible species, yet are known to possess unpleasant odours and result in gastrointesti- 
nal problems if consumed [2,3]. To the best of our knowledge, there is no information available in the literature concerning the chemical composition of these two species.

In this article, we report the results of the GC-MS analyses of volatile and polar compounds, in addition to the sterol fraction obtained from the fruiting bodies of $A$. placomyces and $A$. pseudopratensis. The results can help characterise the species investigated, indicate the presence of some biologically active compounds and shed light upon their reported mild toxicity.

\section{Results and discussion}

The volatile fractions were obtained from the fresh mushrooms' fruiting bodies and analysed as described in the experimental section. The results obtained are outlined in Table 1. The most abundant constituent of the volatiles in both species was phenol: over $40 \%$ in A. placomyces and over $80 \%$ in $A$. pseudopratensis. Besides phenol, the main groups of compounds in the volatile fractions were fatty acids and their esters. Because the extraction was performed using ethanol, it is possible that the ethyl esters are artefacts. Our findings offer the first analytical proof of the presence of phenol in these two species.

The phenol levels detected are not hugely surprising, given the numerous reports of the mushrooms' phenollike odour, in addition to their belonging to the Agaricus section, Xanthodermatei, which is characterised by this typical unpleasant odour. It has been suggested that the production of phenol originates from an evolutionary ancestral biochemical shift, also demonstrated by the Agaricus species of the section Xanthodermatei in defence mechanisms [4]. According to Del Signore et al. [5] phenolic substances in mushrooms may be involved in a chemical defence mechanism against insects and microorganisms, very similar to those described for certain plants (e.g. Salicaceae). Recently, it has been suggested that species with higher evolutionary positions in the section Xanthodermatei demonstrate higher phenol contents [4]. For this reason it could therefore be surmised that $A$. pseudopratensis is a more recently differentiated species than A. placomyces. However, this is only a preliminary hypothesis that will require further more detailed study.

Table I: Volatile constituents of A. placomyces and A. pseudopratensis (\% of the total ion current, GC-MS)*

\begin{tabular}{|c|c|c|}
\hline Compound & A. placomyses (\%) & A. pseudopratensis (\%) \\
\hline \multicolumn{3}{|l|}{ Alcohols and phenols } \\
\hline Phenol & 41.5 & 81 \\
\hline Benzyl alcohol & - & $\operatorname{tr}$ \\
\hline \multicolumn{3}{|l|}{ Aldehydes } \\
\hline Hexanal & 0.9 & - \\
\hline 2-decenal (90) & 0.2 & - \\
\hline 2,4-decadienal & $<0.1$ & - \\
\hline Undecenal (95) & 0.5 & - \\
\hline \multicolumn{3}{|l|}{ Ketones } \\
\hline 2-undecanone & 0.2 & - \\
\hline \multicolumn{3}{|l|}{ Acids } \\
\hline Acetic acid & 1.7 & - \\
\hline Hydroxy acetic acid & 0.3 & - \\
\hline Pentadecanoic acid (93) & 0.3 & - \\
\hline Hexadecanoic acid & 4.5 & 5.5 \\
\hline Hexadecanoic acid - isomer & 1.1 & \\
\hline 9,12-Octadecadienoic acid (linoleic acid) & 2.2 & 9.0 \\
\hline 9-Octadecanoic acid (oleic acid) & 3.7 & - \\
\hline \multicolumn{3}{|l|}{ Ethers } \\
\hline Hydroquinone monopropyl ether (95) & 3.3 & - \\
\hline \multicolumn{3}{|l|}{ Estres } \\
\hline Acetic acid phenyl ester & 0.5 & - \\
\hline Tetradecanoic acid ethyl ester & 0.2 & - \\
\hline Hexadecanoic acid ethyl ester & 5.1 & 8.4 \\
\hline Octadecanoic acid ethyl ester I8:0 (98) & 0.5 & 1.2 \\
\hline Octadecenoic acid ethyl ester $18: \mid$ & 1.1 & - \\
\hline 9,I2-Octadecadienoic acid ethyl ester (89) & 10.1 & - \\
\hline \multicolumn{3}{|l|}{ Terpenoids } \\
\hline Squalene & 0.4 & - \\
\hline
\end{tabular}

*The ion current generated depends on the characteristics of the compound concerned and is not a true quantification.

** In parenthesis: extent of matching (as a percentage) of MS data with the literature values, where the matching is not $100 \%$ 
The polar fractions obtained from the fungal species investigated were analysed by GC-MS after silylation. The derivatisation was necessary in order to increase the volatility of the polar fraction, thereby enabling its analysis by gas chromatography. The results obtained are outlined in Table 2. The presence of phenolics is clearly evident, as is the higher amount of phenol observed in A. pseudopratensis. This finding supports the suggestion of the defensive role of phenolics in section Xanthodermatei [6]. Another characteristic was the presence of the aromatic amino acids tryptophan and tyrosin, but only in A. pseudopratensis.

Sugar alcohols are amongst the major soluble carbohydrates found in fungi [7]. In the butanol fractions of both species we detected a sugar content of around 30\%: glucitol in A. placomyces and a mixture of glucitol and mannitol in A. pseudopratensis. The most abundant constituent of the polar extracts was urea. This finding once again confirms that higher fungi of the family Agaricaceae accumulate substantial amounts of urea in their fruiting bodies [8]. It has been suggested that urea acts as an osmotically favourable nitrogen reserve for fungi [9].

We also investigated the sterol composition of the two Agaricus species. As expected the predominant sterol in A. placomyces, was ergosterol, although two others were detected, each possessing a $\Delta^{7}$ double bond. In A. pseudopratensis only the latter two sterols were present in sub-

Table 2: Constituents of the polar fraction of A. placomyces and A. pseudopratensis (\% of the total ion current, GC-MS)

\begin{tabular}{|c|c|c|}
\hline Compound** & Agaricus placomyses (\%) & Agariricus pseudopratensis (\%) \\
\hline \multicolumn{3}{|l|}{ Alcohols and phenols } \\
\hline Ethylene diol & 0.1 & 0.1 \\
\hline I,3-butane diol (96) & 1.1 & 1.6 \\
\hline Phenol & 0.6 & 1.0 \\
\hline Catechol & 0.3 & 1.0 \\
\hline Resorcinol (98) & 0.2 & - \\
\hline Hydroquinone & - & 1.2 \\
\hline \multicolumn{3}{|l|}{ Aminoacids } \\
\hline Alanine & 1.5 & 1.3 \\
\hline Glycine (98) & 0.2 & 0.2 \\
\hline Valine (96) & 2.8 & 3.0 \\
\hline Leucine & 1.5 & 2.7 \\
\hline Isoleucine(95) & 0.5 & 1.8 \\
\hline Proline & 0.3 & 0.9 \\
\hline Proline-5-oxo (90) & 3.0 & 4.2 \\
\hline Threonine (95) & 0.8 & 0.6 \\
\hline Phenylalanine & 2.5 & 2.3 \\
\hline Tyrosine & - & 1.4 \\
\hline Triptophan & - & 1.4 \\
\hline \multicolumn{3}{|l|}{ N - containing compounds } \\
\hline Urea & 29.5 & 29.0 \\
\hline 9-H-purine-6-OH (hypoxanthine) & 0.4 & - \\
\hline 6-amino-9- $\beta$-D-ribofuranosyl-9H-purine (9I) & $<0.1$ & - \\
\hline Uracyl & - & 0.1 \\
\hline Xanthine & - & 0.1 \\
\hline \multicolumn{3}{|l|}{ Acids } \\
\hline Butanedioic acid & 0.5 & 1.1 \\
\hline Hydroxy butanedioic acid & 1.6 & 2.6 \\
\hline 2-butenedioic acid & 0.7 & 0.6 \\
\hline Glutamic acid & 0.4 & - \\
\hline Panthotenic acid & - & 0.3 \\
\hline 9,12-Octadecadienoic acid & - & 0.1 \\
\hline Hexadecanoic acid & - & 0.2 \\
\hline $\mathrm{H}_{3} \mathrm{PO}_{4}$ & 1.6 & 0.9 \\
\hline \multicolumn{3}{|l|}{ Sugars and sugar alcohols } \\
\hline Glucitol (98) & 35.0 & 10.0 \\
\hline Manitol (98) & - & 9.8 \\
\hline Disaccharide & - & 1.2 \\
\hline
\end{tabular}

*The ion current generated depends on the characteristics of the compound concerned and is not a true quantification.

** In parenthesis: extent of matching (as a percentage) of MS data with the literature values, where the matching is not $100 \%$ 
stantial quantities, with ergosterol detected in trace amounts.

Using column and preparative thin-layer chromatography, a crystalline compound was isolated from the extracts of both species and identified as $5 \alpha, 8 \alpha$-epidioxi$24(\xi)$-methylcholesta-6,22-diene-3 $\beta$-ol through comparison of its spectral data (MS, ${ }^{1} \mathrm{H}$ - and $\left.{ }^{13} \mathrm{C}-\mathrm{NMR}\right)$ with those reported in the literature [10]. The compound was first isolated from these species and might be regarded as an artefact produced from the oxidation of the corresponding $\Delta^{5,7}$ sterol. It is noteworthy that this type of compound has recently been shown to express inhibitory behaviour against the HTLV-1 virus, in addition to demonstrating cytotoxic activity against human breast cancer cell line $\left(\mathrm{MCF}_{7} \mathrm{WT}\right)[10]$.

\section{Conclusion}

The results obtained add to the knowledge on the chemical composition of mushrooms belonging to the genus Agaricus, and help provide further explanation for their reported mild toxicity, which we attribute to their high phenol content similar to that of other Xanthodermatei species [11].

\section{Experimental Collection of the samples}

The macromycetes (age 3 - 5 days), were collected near Plovdiv, Bulgaria, in October 2005.

\section{Extraction}

The fresh fruiting bodies of macromycetes (A. pseudopratensis - $105 \mathrm{~g}$; A. placomyces - $245 \mathrm{~g}$ ) were cut into small pieces and consecutively extracted with ethanol, ethanolchloroform (1:1) and chloroform. The extracts were combined, water was added and the chloroform layers were removed and evaporated in vacuo to yield $1.88 \mathrm{~g}$ of dry residue for A. placomyces and $0.6 \mathrm{~g}$ for A. pseudopratensis.

\section{Isolation and analysis of volatile compounds}

A portion of the chloroform extract (about $300 \mathrm{mg}$ ) was subjected to a four-hour distillation-extraction on Lickens-Nickerson apparatus [12]. The volatile compounds were extracted from the distillate with diethyl ether (yields of volatiles in Table 1), and analysed by GC/MS on a GC Hewlett Packard 6890 + MS 5973 (Hewlett Packard, Palo Alto, California, USA), with a HP5-MS capillary column $(30 \mathrm{~m} \times 0.25 \mathrm{~mm}, 0.25 \mu \mathrm{m}$ film thickness, Agilent Technologies, Wilmington, Delaware, USA). The ion source was set at $250^{\circ} \mathrm{C}$ and the ionisation voltage at $70 \mathrm{eV}$. The temperature was programmed from $40-280^{\circ} \mathrm{C}$ at a rate of $6^{\circ} \mathrm{C} \mathrm{min}-1$, and a helium carrier gas was used used.

\section{Analysis of polar compounds}

A portion of the n-butanol extract ( $5 \mathrm{mg}$ ) was dissolved in $50 \mu \mathrm{L}$ of dry pyridine, before the addition of $75 \mu \mathrm{L}$ of bis(trimethylsilyl)-trifluoroacetamide (BSTFA). The mixture was heated at $80^{\circ} \mathrm{C}$ for $30 \mathrm{~min}$ and analyzed by GC/MS. The silylated extract was investigated by GC/MS using the same instrument described above, with a capillary column HP-5 $(23 \mathrm{~m} \times 0.2 \mathrm{~mm}, 0.5 \mu \mathrm{L}$ film thickness, Agilent Technologies, Wilmington, Delaware, USA). A helium carrier gas was used. The temperature programmed at 100 $-315^{\circ} \mathrm{C}$ at a rate of $5^{\circ} \mathrm{C} \mathrm{min}^{-1}$, with a $10 \mathrm{~min}$ hold at $315^{\circ} \mathrm{C}$.

\section{Identification of compounds}

Identification was carried out by searching commercial library databases. Some components remained unidentified, however, owing to both a lack of authentic samples and library spectra of the corresponding compounds.

\section{Isolation and identification of sterols}

The chloroform extracts was subjected to column chromatography on silica gel with an $n$-hexane - acetone gradient (30:1 - 5:1) to produce several fractions. The third set of fractions, after further purification by preparative TLC (silica gel $\mathrm{G}, n$-hexane - acetone 10:1), yielded sterol mixtures: $23 \mathrm{mg}$ from A. placomyes and $7.9 \mathrm{mg}$ from $A$. pseudopratensis, which were analysed by GC-MS. A gas chromatograph (Hewlett Packard 5890) linked to a mass spectrometer (Hewlett Packard 5972) with a capillary column SPB-50 ( $30 \mathrm{~m} \times 0.32 \mathrm{~mm}, 0.25 \mu \mathrm{m}$ film thickness) was employed. A helium carrier gas was used with a temperature programme set at $270^{\circ} \mathrm{C}-290^{\circ} \mathrm{C}$ at a rate of $4^{\circ} \mathrm{C}$ $\mathrm{min}^{-1}$ with a $20 \mathrm{~min}$ hold. The ion source was set at $250^{\circ} \mathrm{C}$ with the ionisation voltage at $70 \mathrm{eV}$.

From the fourth set of preparative TLC fractions (silica gel, $n$-hexane - methyl ethyl ketone 10:1) obtained from both

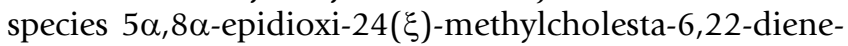
$3 \beta$-ol was isolated $(10.4 \mathrm{mg}$ from $A$. pseudopratensis and 81 $\mathrm{mg}$ from A. placomyces) and characterised through comparison of its EIMS, ${ }^{1} \mathrm{H}$ - and ${ }^{13} \mathrm{C}-\mathrm{NMR}$ spectra with literature data [10].

\section{Authors' contributions}

AP performed the extractions, obtained the volatiles and isolated sterol mixtures, as well as participated in the data analysis and interpretation. KA participated in the data analysis and interpretation. EK performed the isolation and structural identification of the epidioxysterols. DA performed the GC-MS analyses. ML and MG participated in the collection and identification of mushroom material. SP conceived the study and helped draft the manuscript. VB participated in the design and coordination of the study, worked on the data analysis and interpretation 
and helped draft the manuscript. All authors read and approved the final manuscript.

\section{Acknowledgements}

The authors gratefully acknowledge the partial support offered by the National Science Fund (Bulgaria), Contract X-I4I5.

\section{References}

I. Calvo-Bado LC, Noble R, Challen M, Dobrovin-Pennington A, Elliott $\mathrm{T}$ : Sexuality and Genetic Identity in the Agaricus Section Arvenses. Appl Environl Microbiology 2000, 66:728-734

2. Kuo M: Agaricus placomyces. [http://www.mushroomex pert.com/agaricus placomyces.html]. (accessed on 19.10.2007)

3. Agaricus pseudopratensis var. pseudopratensis [http:// www.deltadelpo.it/leggi.asp?articolo $=463$ \&posizione $=426]$. (accessed on 19.10.2007)

4. Pallaci Callaci, Guinbertau J, Rapior S: New Hypotheses from Integration of Morphological Traits Biochemical Data and Molecular Phylogeny in Agaricus spp. The 5th ICMBMP April 2005. [http://www.shroomtalk.com/forum/lofiversion/index.php/ t7455.html]. (accessed on 2I.10.2007)

5. Del Signore A, Romeo F, Giaccio M: Content of phenolic substance in basidiomycetes. Mycol Res 1997, 101:552-556.

6. Stoop JMH, Mooibroek $\mathrm{H}$ : Advances in genetic analysis and biotechnology of the cultivated button mushroom, Agaricus bisporus. Appl Microbiol Biotechnol 1999, 52:474-483.

7. Lewis DH, Smith DC: Sugar Alcohols (Polyols) in Fungi and Green Plants. I. Distribution, Physiology and Metabolism. New Phytologist 1967, 66:143-184.

8. Wagemaker MJM, Welboren W, van der Drift C, Jetten MSM, Van Griensven LJLD, Op den Camp HJM: The ornithine cycle enzyme arginase from Agaricus bisporus and its role in urea accumulation in fruiting bodies. Biochim Biophys Acta (BBA) - Gene Structure and Expression 2005, 1681:107-I I5.

9. Wagemaker MJM, Eastwood DC, van der Drift C, Jetten MSM, Burton K, Van Griensven LJLD, Op den Camp HJM: Expression of the urease gene of Agaricus bisporus: a tool for studying fruiting body formation and post-harvest development. Appl Microbiol Biotechnol 2006, 7 I:486-492.

10. Gauvin A, Smadja J, Aknin M, Faure R, Gaydou E-M: Isolation of bioactive $5 \mathrm{a}, 8 \mathrm{a}$-epidioxy sterols from the marine sponge Luffariella cf. variabilis. Can J Chem 2000, 78:986-992.

II. Gill M, Strauch RJ: Constituents of Agaricus xanthodermus Genevier: the first naturally endogenous azo compound and toxic phenolic metabolites. Z Naturforsch [C] 1984, 39: 1027-1029.

12. Hendriks H, Geerts HJ, Malingre M: The occurrence of valeranone and crypto-fauronol in the essential oil of Valeriana officinalis $L$. s. I. collected in the northern part of The Netherlands. Pharmac Wekblad Scient Edition 198I, I I6:1316-1320.

\section{Publish with ChemistryCentral and every scientist can read your work free of charge \\ "Open access provides opportunities to our colleagues in other parts of the globe, by allowing anyone to view the content free of charge." \\ W. Jeffery Hurst, The Hershey Company. \\ - available free of charge to the entire scientific community \\ - peer reviewed and published immediately upon acceptance \\ - cited in PubMed and archived on PubMed Central \\ - yours - you keep the copyright \\ Submit your manuscript here: \\ http://www.chemistrycentral.com/manuscript/}

